\title{
Diversity of the genus Sheathia (Batrachospermales, Rhodophyta) in northeast India and east Nepal
}

\author{
Orlando Necchi Jr., ${ }^{1, *}$, John A. West ${ }^{2}$, E. K. Ganesan ${ }^{3, a}$, Farishta Yasmin ${ }^{4}$, Shiva Kumar Rai ${ }^{5}$ \\ and Natalia L. Rossignolo ${ }^{1}$
}

${ }^{1}$ Department of Zoology and Botany, São Paulo State University, Rua Cristóvão Colombo, 2265, 15054-000 S. José Rio

Preto, São Paulo, Brazil

${ }^{2}$ School of Biosciences 2, University of Melbourne, Parkville VIC 3010, Australia

${ }^{3}$ Instituto Oceanográfico, Universidad de Oriente, Cumaná 6101, Venezuela

${ }^{4}$ Department of Botany, Nowgong College, Nagaon, 782001, Assam, India

${ }^{5}$ Department of Botany, Tribhuvan University, Post Graduate Campus, Biratnagar, Nepal

Freshwater red algae of the order Batrachospermales are poorly studied in India and Nepal, especially on a molecular basis. During a survey in northeast India and east Nepal, six populations of the genus Sheathia were found and analyzed using molecular and morphological evidence. Phylogenetic analyses based on the rbcL gene sequences grouped all populations in a large clade including our S. arcuata specimens and others from several regions. Sheathia arcuata represents a species complex with a high sequence divergence and several smaller clades. Samples from India and Nepal were grouped in three distinct clades with high support and representing new cryptic species: a clade formed by two samples from India, which was named Sheathia assamica sp. nov.; one sample from India and one from Nepal formed another clade, named Sheathia indonepalensis sp. nov.; two samples from Nepal grouped with sequences from Hawaii and Indonesia (only 'Chantransia' stages) and gametophytes from Taiwan, named Sheathia dispersa sp. nov. Morphological characters of the specimens from these three species overlap one another and with the general circumscription of $S$. arcuata, which lacks the heterocortication (presence of bulbous cells in the cortical filaments) present in other species of the genus Sheathia. Although the region sampled is relatively restricted, the genetic diversity among specimens of these three groups was high and not closely related in the phylogenetic relationship with the other clades of $S$. arcuata. These data corroborate information from other groups of organisms (e.g., land and aquatic plants) that indicates this region (Eastern Himalaya) as a hotspot of biodiversity.

Key Words: biodiversity; Eastern Himalaya; freshwater Rhodophyta; molecular systematics; morphometrics; rbcL

\section{INTRODUCTION}

Members of the freshwater red algal order Batrachospermales are distinguished from those in the closely related Thoreales by having uniaxial rather than multiaxial gametophytes (Müller et al. 2002, Entwisle et al. 2009).
The current characterization of the order is based on the following combination of characters (Pueschel and Cole 1982, Garbary and Gabrielson 1990, Kumano 2002, Entwisle et al. 2009): (1) thalli heterotrichous, uniaxial,
(9) $\$$ This is an Open Access article distributed under the terms of the Creative Commons Attribution Non-Commercial License (http://creativecommons.org/licenses/by-nc/3.0/) which permits unrestricted non-commercial use, distribution, and reproduction in any medium, provided the original work is properly cited.
Received August 18, 2019, Accepted October 30, 2019

*Corresponding Author

E-mail: o.necchi@unesp.br

Tel: +55-17-32212406

${ }^{\text {a }}$ Present address: 3-A Srinivas Terrace, 52, II Main Road, Gandhi Nagar, Adyar, Chennai, 600020, Tamil Nadu, India 
gelatinous, or cartilaginous; (2) axial cells bearing determinant lateral assimilatory filaments; (3) pit plugs with two cap layers, with an expanded dome-shaped outer layer; tetraspores lacking, meiosis in diploid vegetative cells giving rise to haploid axes by somatic meiosis; (4) multiple discoid chloroplasts lacking pyrenoids; (5) exclusively freshwater distribution. A comprehensive phylogenetic study (Entwisle et al. 2009) of the order recognized a single family (Batrachospermaceae) with several genera, with the genus paraphyletic genus Batrachospermum being the most diverse. Investigations focusing on the infrageneric taxa of the genus have been conducted to correct the paraphyly of Batrachospermum. As a consequence, several sections have been raised to the genus level: Kumanoa (former sections Contorta and Hybrida) (Entwisle et al. 2009), Sheathia (former section Helminthoidea) (Salomaki et al. 2014), Torularia (= Atrophycus, former section Setacea) (Rossignolo and Necchi 2016), Virescentia (formerly a section with the same name), Acarposporophycos (former section Acarposporophytum) and Visia (former section Aristata) (Necchi et al. 2019a), Montagnia (Necchi et al. 2019b).

The genus Sheathia was proposed as taxonomically separate based on DNA sequences of the RuBisCO largesubunit gene $(r b c \mathrm{~L})$ gene, the mitochondrial encoded cytochrome $c$ oxidase subunit 1 (COI-5P) barcode region and the rDNA internal transcribed spacer 1 and 2 (Salomaki et al. 2014). Morphology also provided good taxonomic evidence to separate the genus, particularly the almost ubiquitous presence of heterocortication (i.e., the presence of both cylindrical and bulbous cells in the cortical filaments covering the main axis). This synapomorphy is evident for all species in the genus, except Sheathia arcuata (Kylin) Salomaki et Vis. Salomaki et al. (2014) recognized ten species within the genus with molecular data reported for eight species. Guiry and Guiry (2019) listed 13 currently accepted species as taxonomically valid. Most species in the genus have relatively little variation in DNA sequences for those three markers used by Salomaki et al. (2014) but S. arcuata is an exception. Molecular sequence data indicated higher genetic diversity than is recognized within a single species (e.g., $>6 \%$ variation in $r b c \mathrm{~L}$ sequences in contrast to roughly $<2 \%$ in other species).

On the other hand, no morphological character was evident and a wide plasticity has been reported within this species (Vis et al. 2010). These data suggest cryptic speciation in S. arcuata, with the taxon consisting of a complex involving several species.

Sheathia has been poorly documented in India and Ne- pal. Balakrishnan and Chaugule (1980) reported Sheathia boryana (Sirodot) Salomaki and Vis (as Batrachospermum ectocarpum Sirodot) with a detailed morphological description for specimens collected in South India (Ganesan et al. 2018). In Nepal, the only record of a member of Batrachospermales is by Shrestha and Manandhar (1983) who listed B. gelatinosum (Linnaeus) De Candolle (as B. moniliforme Roth) from the Kathmandu valley.

In February 2018, we explored northeast India and east Nepal for members of the freshwater red algal order Batrachospermales in order to document the diversity in poorly collected areas of a biodiversity hotspot designated Eastern Himalaya (WWF-US, Asia Program 2005, Allen et al. 2010), a collection trip was conducted searching particularly for members of the freshwater red algal order Batrachospermales in some regions of northeast India and east Nepal. The most representative group observed was the genus Sheathia with six populations collected in those areas that were analyzed for DNA sequence and morphological data.

\section{MATERIALS AND METHODS}

Sheathia specimens were collected in six locations, three in northeast India and three in east Nepal (Table 1). These areas are within a biodiversity hotspot known as the Eastern Himalaya Biodiversity Hotspot (WWF-US, Asia Program 2005, Allen et al. 2010). The region comprises the lowlands of western Nepal and the montane regions of central and eastern Nepal; the state of Sikkim, the northern extent of West Bengal in India including Darjeeling District; Bhutan in its entirety; and the northeastern Indian states of Assam, Arunachal Pradesh, Manipur, Mizoram, Tripura, Meghalaya and Nagaland (Allen et al. 2010). Our collections were conducted in the regions of the northeastern Indian State of Assam and eastern Nepal.

Specimens for morphological studies were preserved in $4 \%$ formaldehyde, and voucher specimens were lodged at Herbarium SJRP (Thiers 2019). Specimens for DNA analysis were blotted dry with tissue and preserved in silica desiccant.

Morphological analyses were carried out for all characters previously determined to be diagnostic in relevant studies of the genus (Kumano 2002, Vis et al. 2010, Salomaki et al. 2014). For morphometric variables, 20 measurements or counts were taken for each character in each sample (Necchi and Zucchi 1997). Photomicrographs were taken with a Leica DFC 320 digital camera 
with a LAS capture and image analysis software coupled to a Leica DM 5000 microscope (Leica Microsystems, Wetzlar, Germany).

Principal component analysis (PCA) (Everitt and Dunn 2001) was applied to evaluate the relationship of morphometric variables among sampling sites. Analysis was performed with Minitab 10 Statistical Software (Minitab Inc., State College, PA, USA, http://www.minitab.com) from a standardized matrix using ranging for standardization and the Pearson correlation coefficient.

Protocols for DNA extraction, polymerase chain reaction (PCR) amplification, purification and sequencing are the same as those described in our previous studies: Rossignolo and Necchi (2016), Necchi et al. (2019a, 2019b). Two molecular markers were analyzed: the barcode region of the COI-5P, and the plastid-encoded $r b c \mathrm{~L}$. PCR reactions for COI-5P worked for only two out of the six samples and resulted in partial sequences. Thus, COI5P marker was not included in the analyses.

For phylogenetic analyses of the $r b c L$ sequence data, a GTR + I + G was determined as the best-fit model of sequence evolution by the Akaike Information Criterion using jModelTest 2.1.4 (Darriba et al. 2012). Maximum likelihood (ML) topologies and bootstrap values from 10,000 replicates were inferred using RAxML graphic user interface ver. 1.5 (Silvestro and Michalak 2012). Bayesian analysis (BA) was performed in MrBayes 3.2 (Ronquist and Huelsenbeck 2003) with three runs of five chains of Metropolis coupled Markov Chain Monte Carlo for $5 \times$ $10^{6}$ generations. The first 500,000 chains were removed as burn-in prior to determining the posterior probabilities.

\section{RESULTS}

\section{Molecular analyses}

The $r b c \mathrm{~L}$ gene sequences of the samples from India and Nepal were compared with 48 previously published sequences of Sheathia obtained from GenBank (Fig. 1). $\mathrm{BA}$ and ML analyses of the $r b c \mathrm{~L}$ alignment yielded similar trees, showing strong support for most species presently recognized within the genus Sheathia and particularly for the clades including our sequences from India and Nepal (Fig. 1). Our samples were all grouped within the large clade named $S$. arcuata, which actually represents several species and is named the $S$. arcuata complex. Sequences from India and Nepal were spread in three distinct clades, all representing new species. A first and basal clade was formed by two samples from India (sites 2 and 3 ), which was sister to another clade with one sequence from New Zealand and one from United States (Fig. 1). The level of divergence between the two latter sequences $(1.6 \%)$ indicates that they are two separate species. Sequence divergence among the two Indian samples was $0.5 \%$. The other sequences were positioned within a large clade with several species of the $S$. arcuata complex: (1) $S$. arcuata from Europe-this should be recognized as $S$. arcuata "stricto sensu" since the species was described from Europe (Sweden); (2) S. longipedicellata from China-sequences from China were described as different species but they all consist of a single species for which the oldest epithet was applied; (3) a clade with two sequences from Nepal (sites 1 and 2) and others from Hawaii and

Table 1. Information on samples of Sheathia from India and Nepal included in this study

\begin{tabular}{|c|c|c|}
\hline Site designation & Collection information & GenBank accession No. $(r b c \mathrm{~L})$ \\
\hline India site 1 & $\begin{array}{l}\text { Assam State, Nagaon District, Chapanalla, } 26^{\circ} 19^{\prime} 13.7^{\prime \prime} \text { N, 92 }{ }^{\circ} 54^{\prime} 07.3^{\prime \prime} \text { E, eleva- } \\
\text { tion } 86 \text { m, coll. O. Necchi Jr. et al., Feb 23, } 2018 \text { (SJRP 32575) }\end{array}$ & MN481449 \\
\hline India site 2 & $\begin{array}{l}\text { Assam State, Morigaon District, Amsoi, } 26^{\circ} 07^{\prime} 19.6^{\prime \prime} \text { N, 92²6'24.9" E, elevation } \\
110 \text { m, coll. O. Necchi Jr. et al., Feb 24, } 2018 \text { (SJRP 32576) }\end{array}$ & MN481450 \\
\hline India site 3 & $\begin{array}{l}\text { Assam State, Hatidandi, at Burapahar Tea Estate, Kaziranga National Park, } \\
\text { down the hill called Elephant Corridor, } 26^{\circ} 33^{\prime} 31.5^{\prime \prime} \text { N, } 93^{\circ} 10^{\prime} 16.5^{\prime \prime} \text { E, elevation } \\
91 \mathrm{~m} \text {, coll. O. Necchi Jr. et al., Feb 25, } 2018 \text { (SJRP 32577) }\end{array}$ & MN481451 \\
\hline Nepal site 1 & $\begin{array}{l}\text { Province No. 1, Koshi Zone, Morang District, Sundarharaicha Municipality, } \\
\text { ward No. 5, Khayer Khola, } 26^{\circ} 41^{\prime} 24.8^{\prime \prime} \text { N, } 87^{\circ} 19^{\prime} 18.1^{\prime \prime} \text { E, elevation } 120 \text { m, } \\
\text { coll. O. Necchi Jr. et al., Feb 21, } 2018 \text { (SJRP 32578) }\end{array}$ & MN487058 \\
\hline Nepal site 2 & $\begin{array}{l}\text { Province No. 1, Koshi Zone, Morang District, Sundarharaicha Municipality, } \\
\text { ward No. 5, Lati Khola, } 26^{\circ} 42^{\prime} 10.9^{\prime \prime} \text { N, } 87^{\circ} 19^{\prime} 15.8^{\prime \prime} \text { E, elevation } 127 \text { m, } \\
\text { coll. O. Necchi Jr. et al., Feb 21, } 2018 \text { (SJRP 32579) }\end{array}$ & MN487059 \\
\hline Nepal site 3 & $\begin{array}{l}\text { Province No. 1, Koshi Zone, Morang District, Sundarharaicha Municipality, } \\
\text { ward No. 5, Budhi Khola, } 26^{\circ} 42^{\prime} 41.5^{\prime \prime} \text { N, 87¹9'16.1" E, elevation } 131 \text { m, } \\
\text { coll. O. Necchi Jr. et al., Feb 21, } 2018 \text { (SJRP 32580) }\end{array}$ & MN487060 \\
\hline
\end{tabular}




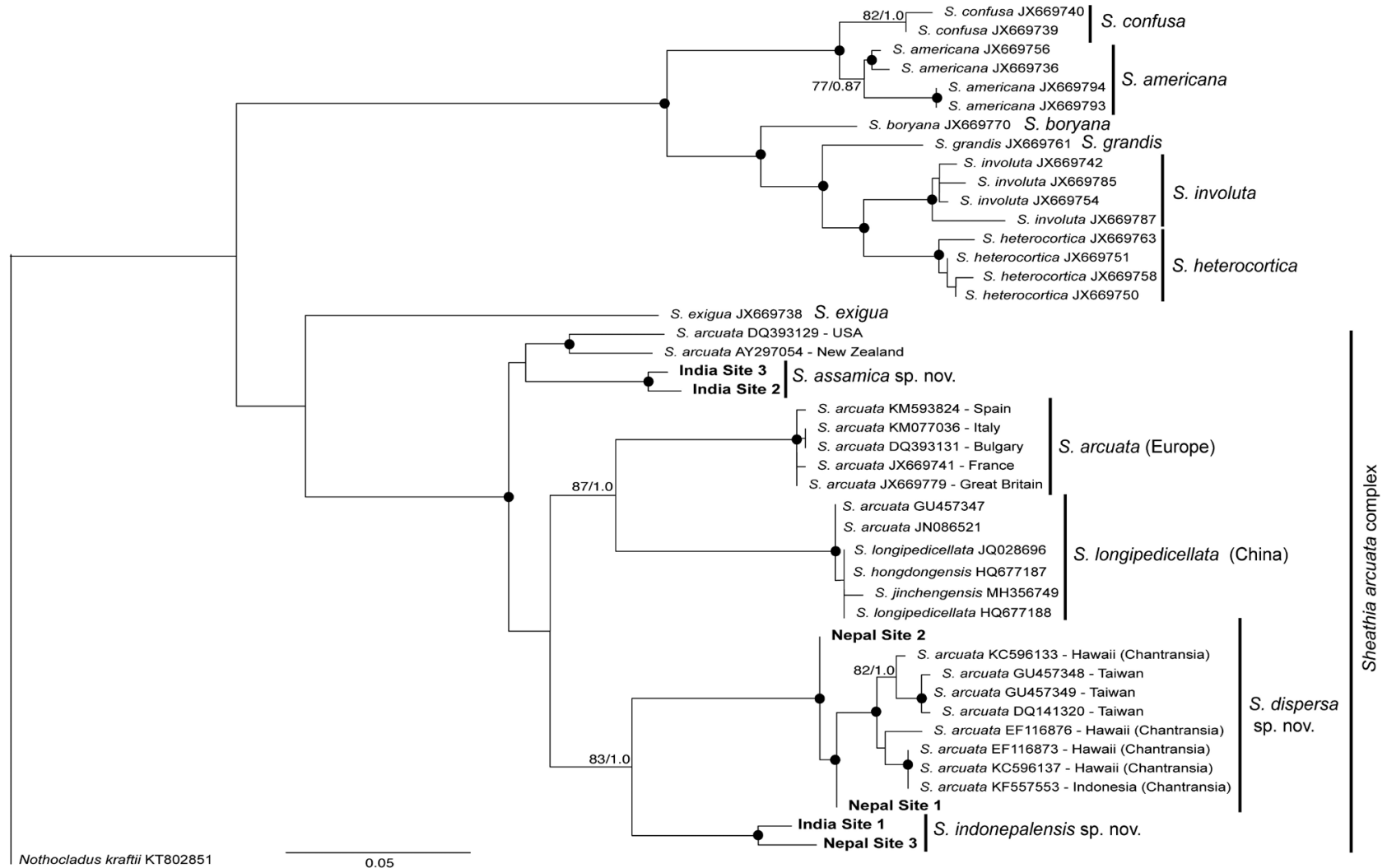

Fig. 1. Maximum likelihood (ML) tree of Sheathia inferred from $r b c L$ sequences. ML bootstrap values ( $\geq 70 \%)$ and Bayesian posterior probabilities $(\geq 0.85)$ are shown at branches. Bold letters indicate newly generated sequences in this study.

Indonesia (represented only by the 'Chantransia' stage) and sequences of gametophytes from Taiwan; sequence divergence in this clade was $0.1-0.9 \%$; (4) a clade with one sequence from India (site 1) and one from Nepal (site 3) with sequence divergence of $1 \%$.

\section{Morphological analyses}

The morphological variability observed in the six populations from India and Nepal was similar to that previously observed in specimens of $S$. arcuata from other regions of the world evidencing a wide plasticity. Ranges for most morphometric characters observed within and among sampling sites encompass the morphometric values reported for S. arcuata complex (Table 2). Some character ranges extended beyond the the upper limits reported previously: whorl diameter, fascicle cell number, internode length, carposporophyte and spermatangia diameter. We found the highest values for seven out of the 12 morphometric variables analyzed in one sample from Nepal (site 3).
Table 2. Results of principal component analysis for morphometric variables of samples of Sheathia from India and Nepal

\begin{tabular}{lcc}
\hline \multicolumn{1}{c}{ Variable } & Component $\mathbf{1}$ Component 2 \\
\hline Eigenvalue & 5.34 & 3.21 \\
Percent & 44.47 & 26.76 \\
Loading & & \\
Carpogonial branch cell number & $\mathbf{0 . 9 6 6}$ & -0.263 \\
Whorl diameter & $\mathbf{0 . 8 9 0}$ & 0.430 \\
Carpogonium length & $\mathbf{0 . 8 7 8}$ & -0.224 \\
Fascicle cell number & $\mathbf{0 . 8 5 6}$ & -0.065 \\
Carpogonial branch length & $\mathbf{0 . 8 4 6}$ & 0.302 \\
Spermatangium diameter & $\mathbf{0 . 7 9 8}$ & 0.379 \\
Carposporophyte diameter & $\mathbf{0 . 7 2 0}$ & 0.062 \\
Carposporophyte number & 0.213 & -0.249 \\
Internode length & -0.114 & $\mathbf{0 . 9 6 4}$ \\
Carposporangium diameter & 0.255 & $\mathbf{0 . 9 6 0}$ \\
Carposporangium length & 0.322 & $\mathbf{0 . 8 4 7}$ \\
Cortical cell diameter & 0.091 & 0.187 \\
\hline
\end{tabular}

The most significant variables for each component are in bold. 


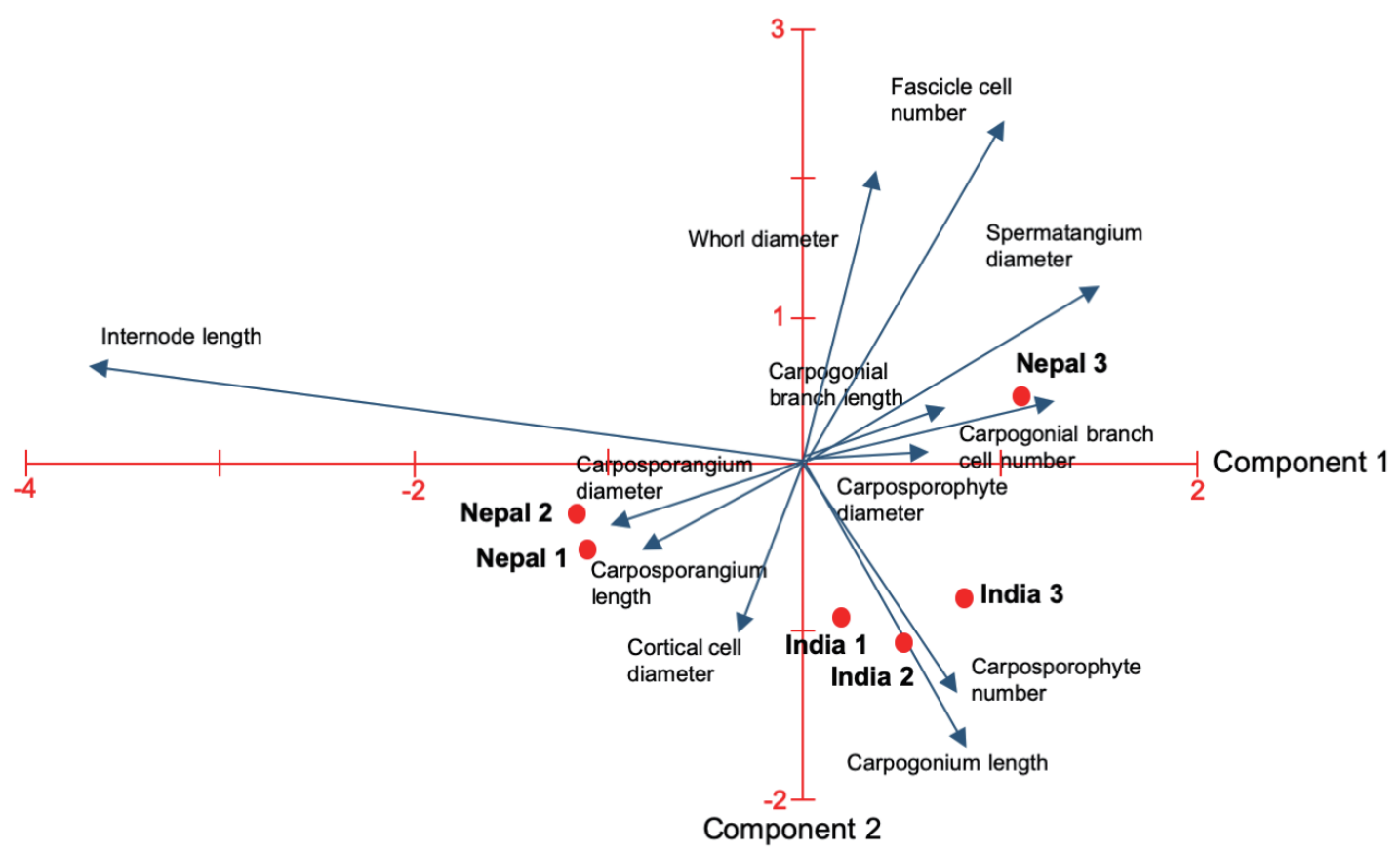

Fig. 2. Biplot diagram of the principal components analysis based on morphometric characters of Sheathia populations from India and Nepal. Eigenvalues and loadings for morphometric variables are listed in Table 2. Sample codes as in Table 1.

PCA revealed that the first two principal components accounted for $71.3 \%$ of the total variance in the data (Table 2). The most significant variables for component 1 were (Table 2, Fig. 2): carpogonial branch cell number, whorl diameter, carpogonium length, fascicle cell number, carpogonial branch length, and spermatangium and carposporophyte diameter. In contrast, for component 2 internode length, carposporangium diameter and length were the most influential variables. Carposporophyte number and cortical cell diameter were the least important morphometric variables.

One population (Nepal site 3) was positioned distantly from all others mostly due to the higher values of the seven most significantly variables for component 1 (Tables 2 \& 3, Fig. 2). The other two populations from Nepal (sites 1 and 2) were grouped together basically due to the higher values for internode length, carposporangium length and diameter (Tables $2 \& 3$, Fig. 2). The three populations from India were grouped together and had intermediate values within the ranges for all morphometric variables.

\section{Taxonomic proposals}

The fact that phylogenetic analyses revealed that $r b c \mathrm{~L}$ sequences from India and Nepal formed three clades with high support and with divergence levels in each clade within the limit to represent single entities sustains the recognition of three new species that are described below.

\section{Sheathia assamica Necchi, J. A. West, E. K. Ganesan et F.} Yasmin sp. nov. (Fig. 3A-F)

Description. Plants dioecious, irregularly branched. Male plants with separated and spherical whorls, female plants with confluent and barrel-shaped whorls, 374-870 $\mu \mathrm{m}$ in diameter. Primary fascicles straight, with curved distal ends, with 11-16 cell layers; proximal cells cylindrical or ellipsoidal, distal cells ellipsoid; secondary fascicles lacking. Internode 312-718 $\mu \mathrm{m}$ long. Cortication of the main axis with two or three layers of filaments, composed only of cylindrical cells, $4.8-10.3 \mu \mathrm{m}$ in diameter. Spermatangia spherical, terminal on primary fascicles, 5.5-9.2 $\mu \mathrm{m}$ in diameter. Carpogonial branches composed of 3-9 cylindrical or ellipsoid cells, developing from the periaxial cells, proximal or middle cells of primary fascicles, rarely from carpogonial branches, 24.1-91.8 $\mu \mathrm{m}$ long; involucral filaments composed of 1-5 ellipsoidal or fusiform cells; carpogonia 20.5-30.5 $\mu \mathrm{m}$ long, with sessile, club-shaped or ellipsoidal trichogynes. Carposporophytes pedunculate, spherical or subspherical, contained within the whorls or exerted, 1-3 per whorl, small, 98.0-220.2 $\mu \mathrm{m}$ in diameter; gonimoblast filaments 


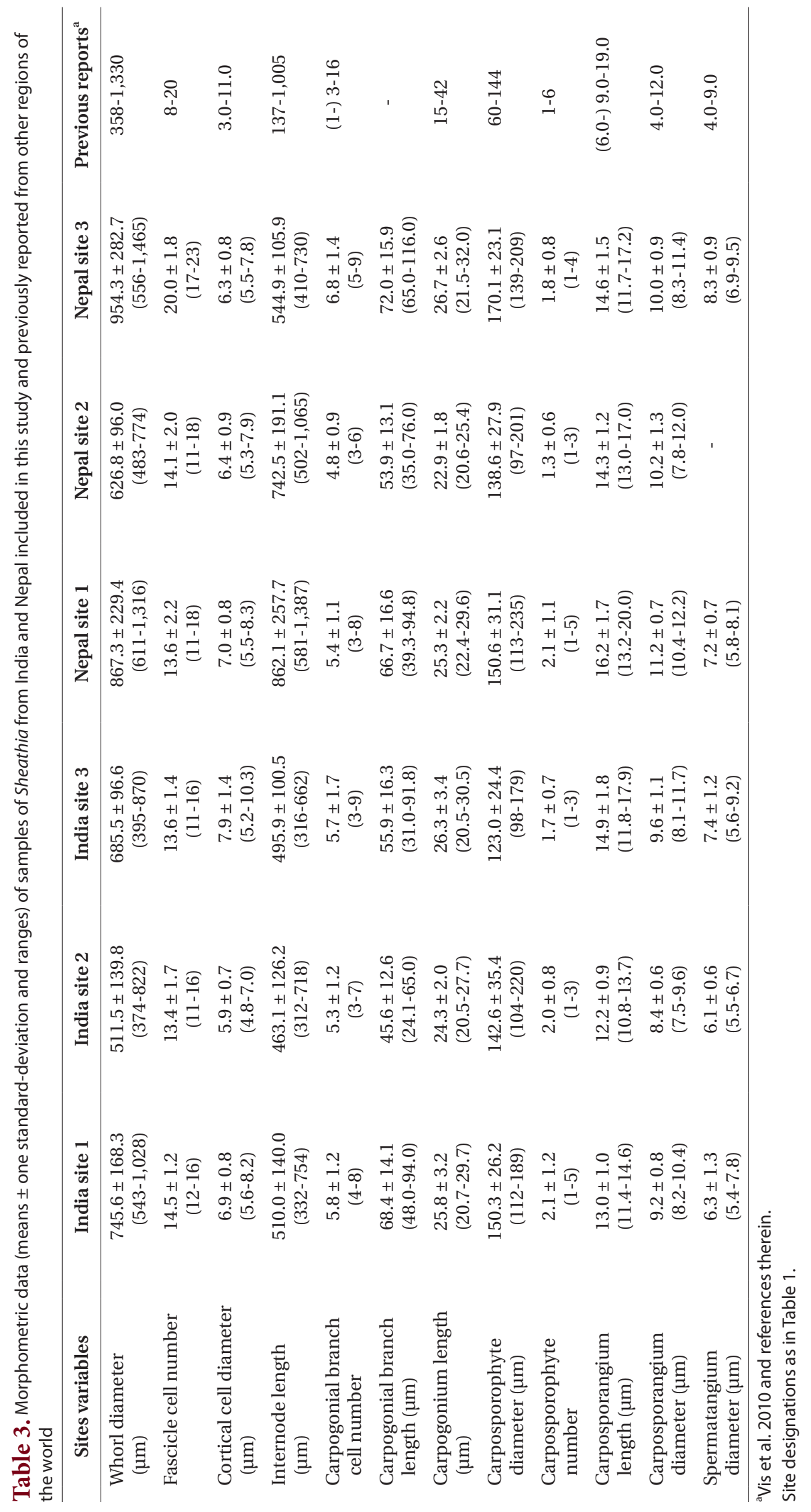



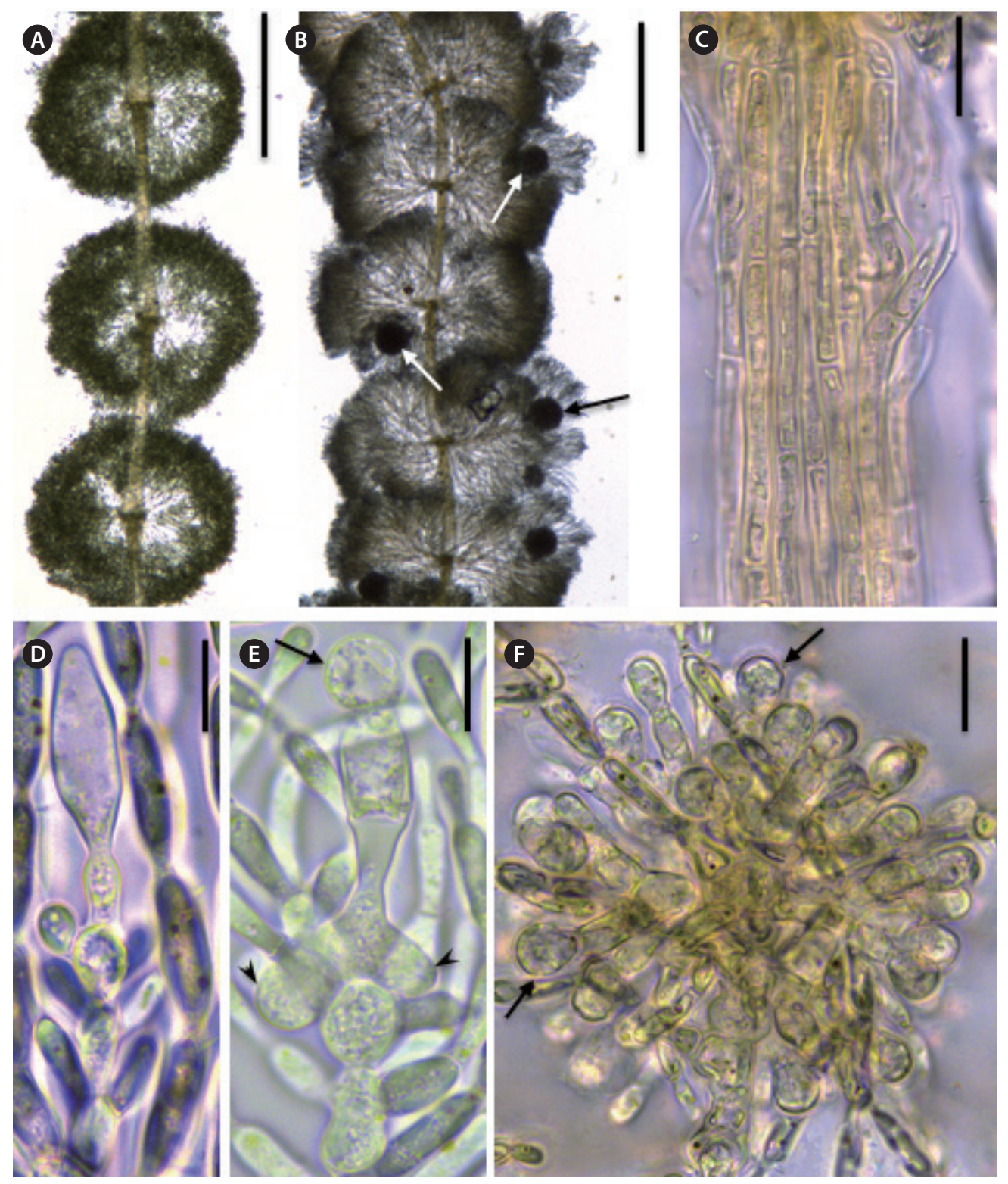

Fig. 3. Photomicrographs with key morphological characters of Sheathia assamica sp. nov. Herbarium specimen codes as in Table 1. (A) Separated and spherical whorls of a male plant. (B) Confluent and barrel-shaped whorls of a female plant with pedunculate and exerted carposporophytes (arrows). (C) Detail of cortical filaments with cylindrical cells. (D) Mature carpogonium with ellipsoidal trichogyne. (E) Fertilized carpogonium with club-shaped trichogyne, attached spermatium (arrow) and gonimoblast initials (arrowheads). (F) Carposporophyte with obovoid carposporangia (arrows). All photomicrographs taken from the holotype (SJRP 32576). Scale bars represent: A \& B, $500 \mu \mathrm{m} ; C$ \& F, $25 \mu \mathrm{m} ; \mathrm{D} \& \mathrm{E}, 10$ $\mu \mathrm{m}$.

densely arranged, composed of two to four cylindrical or barrel-shaped cells; carposporangia obovoid, 10.8-17.9 $\mu \mathrm{m}$ long, 7.5-11.7 $\mu \mathrm{m}$ wide.

Holotype. India, Assam, Morigaon District, Amsoi, $26^{\circ} 07^{\prime} 19.6^{\prime \prime}$ N, 92²6 $24.9^{\prime \prime}$ E, coll. O. Necchi Jr., F. Yasmin, J. A. West and E. K. Ganesan, Feb 24, 2018 (SJRP 32576).

Paratype. India, Assam, Hatidandi, at Burapahar Tea Estate, Kaziranga National Park, down the hill called El- ephant Corridor, $26^{\circ} 33^{\prime} 31.5^{\prime \prime} \mathrm{N}, 93^{\circ} 10^{\prime} 16.5^{\prime \prime} \mathrm{E}$, coll. O. Necchi Jr., F. Yasmin, J. A. West and E. K. Ganesan, Feb 25, 2018 (SJRP 32577).

Etymology. The species epithet refers to the known geographic distribution of the species restricted to the Indian State of Assam.

DNA sequences. MN487450, MN487451. 

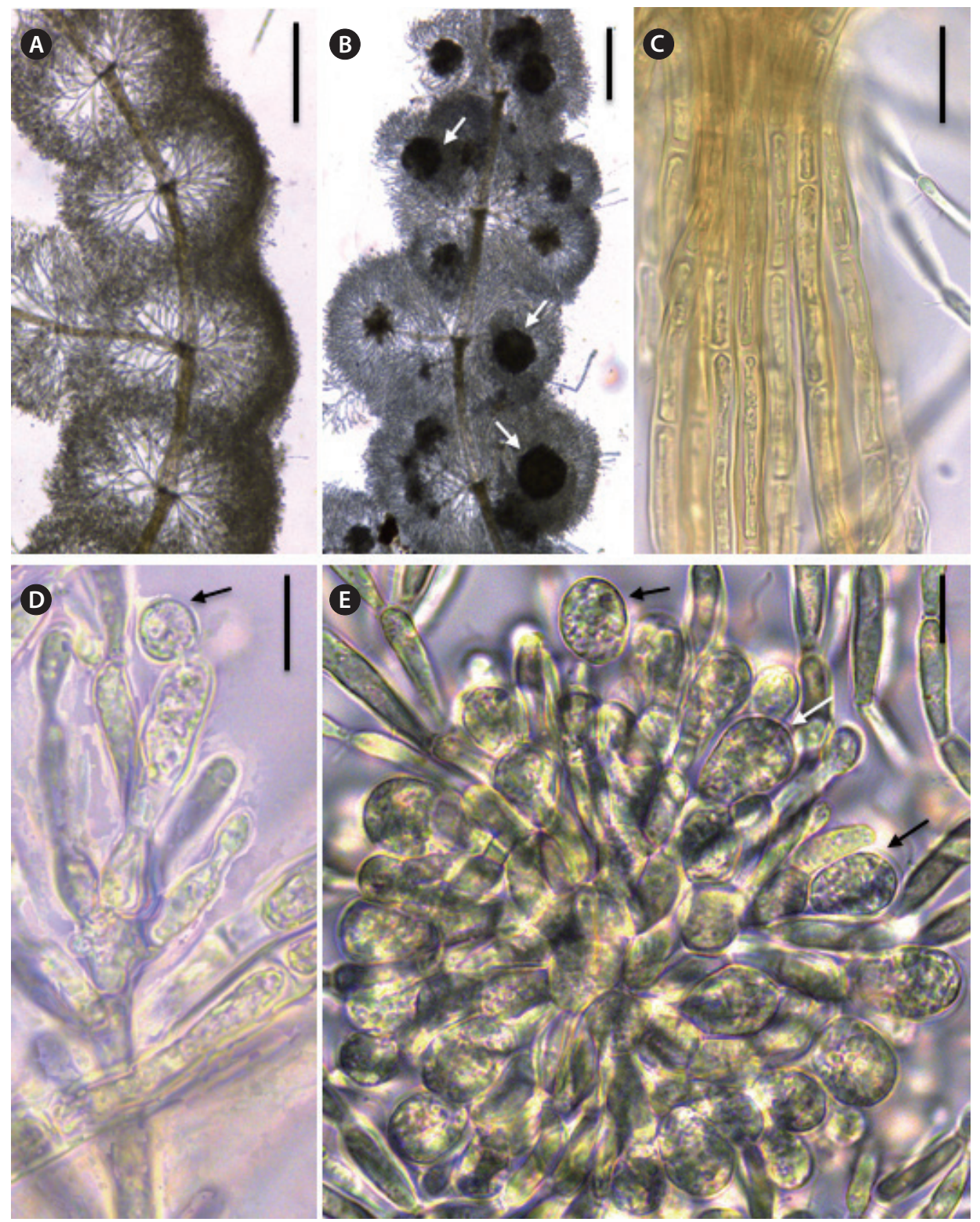

Fig. 4. Photomicrographs with key morphological characters of Sheathia indonepalensis sp. nov. Herbarium specimen codes as in Table 1. (A) Confluent and barrel-shaped whorls of a male plant. (B) Confluent and barrel-shaped whorls of a female plant with pedunculate carposporophytes (arrows). (C) Detail of cortical filaments with cylindrical cells. (D) Fertilized carpogonium with club-shaped trichogyne and attached spermatium (arrow). (E) Carposporophyte with obovoid carposporangia (arrows). All photomicrographs taken from the holotype (SJRP 32575). Scale bars represent: $A \& B, 250 \mu m ; C, 25 \mu m ; D \& E, 10 \mu m$.

\section{Sheathia indonepalensis Necchi, J. A. West, E. K. Gane-} san, S. K. Rai et F. Yasmin sp. nov. (Fig. 4A-E)

Description. Plants dioecious, irregularly branched. Male and female plants with confluent or separated, barrel-shaped or spherical whorls, 543-1,465 $\mu$ m wide. Primary fascicles straight, with curved distal ends, with 12-23 cell layers; proximal cells cylindrical or ellipsoidal, distal cells ellipsoid; secondary fascicles lacking. Internode 332-754 $\mu \mathrm{m}$ long. Cortication of the main axis with two or three layers of filaments, composed only of cylindrical cells, 5.5-8.2 $\mu \mathrm{m}$ wide. Spermatangia spherical or obovoid, terminal on primary fascicles, 5.5-9.5 $\mu \mathrm{m}$ wide. Carpogonial branches composed of 4-9 cylindrical or ellipsoid cells, developing from the periaxial cells or proximal cells of primary fascicles, 48.0-116.0 $\mu \mathrm{m}$ long; involucral filaments composed of 1-5 ellipsoidal or fusiform cells; carpogonia 20.7-32.0 $\mu \mathrm{m}$ long, with sessile, clubshaped trichogynes. Carposporophytes pedunculate, 

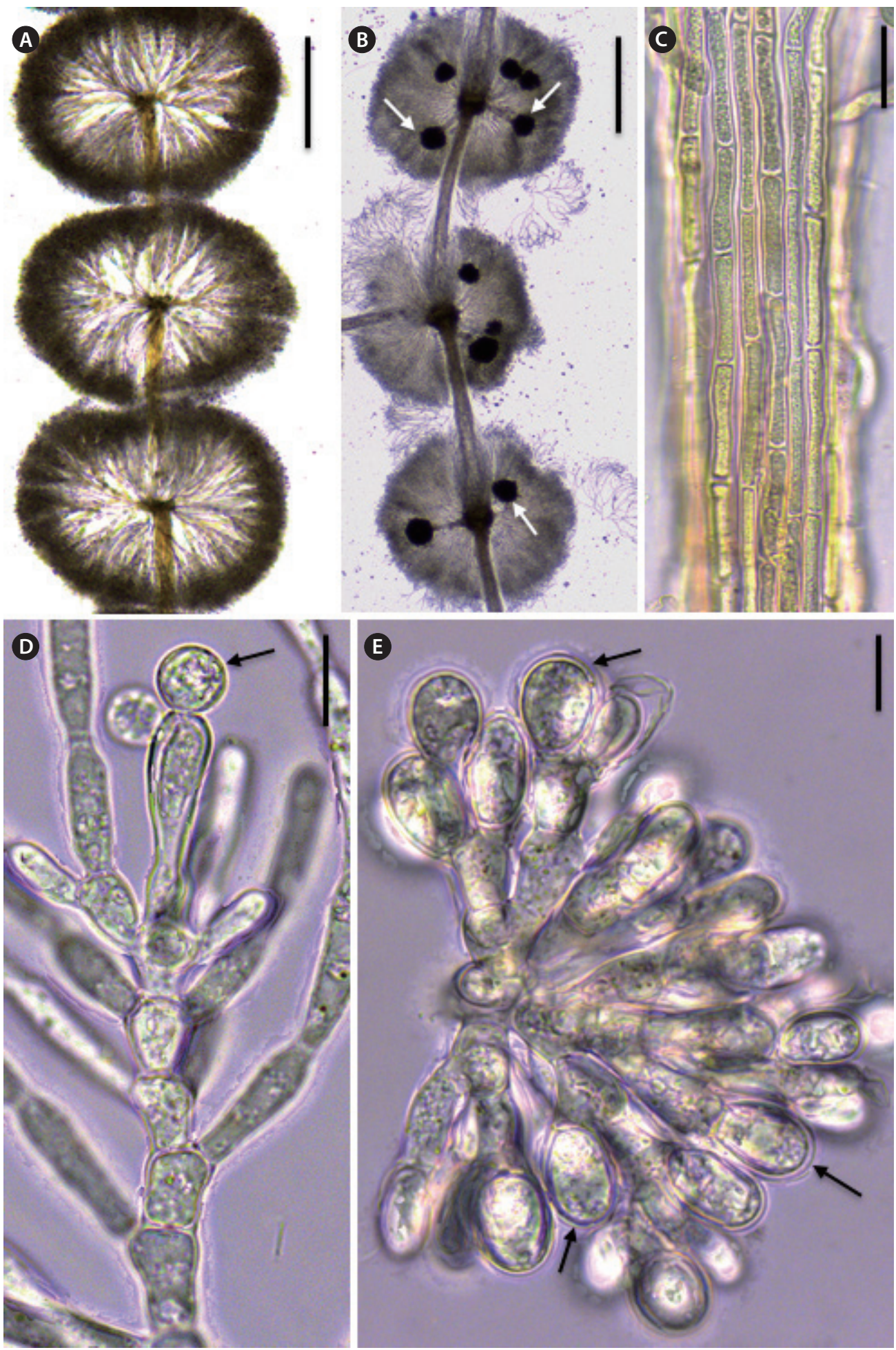

Fig. 5. Photomicrographs with key morphological characters of Sheathia dispersa sp. nov. Herbarium specimen codes as in Table 1. (A) Separated and spherical whorls of a male plant. (B) Separated and spherical whorls of a female plant with pedunculate carposporophytes (arrows). (C) Detail of cortical filaments with cylindrical cells. (D) Fertilized carpogonium with club-shaped trichogyne and attached spermatium (arrow). (E) Carposporophyte with obovoid carposporangia (arrows). All photomicrographs taken from the holotype (SJRP 32578). Scale bars represent: A $250 \mu \mathrm{m} ; \mathrm{B}, 500 \mu \mathrm{m} ; \mathrm{C}, 25 \mu \mathrm{m} ; \mathrm{D} \& \mathrm{E}, 10 \mu \mathrm{m}$. 
spherical or subspherical, contained within the whorls or exerted, 1-5 per whorl, small, 112.0-209.0 $\mu \mathrm{m}$ in diameter; gonimoblast filaments densely arranged, composed of two to four cylindrical or barrel-shaped cells; carposporangia obovoid, 11.4-17.2 $\mu \mathrm{m}$ long, 8.2-11.4 $\mu \mathrm{m}$ wide.

Holotype. India, Assam, Nagaon District, Chapanalla, $26^{\circ} 19^{\prime} 13.7^{\prime \prime}$ N, 92 ${ }^{\circ} 54^{\prime} 07.3^{\prime \prime}$ E, coll. O. Necchi Jr., F. Yasmin, J. A. West and E. K. Ganesan, Feb 23, 2018 (SJRP 32575).

Paratype. Nepal, Province No. 1, Koshi Zone, Morang District, Sundarharaicha Municipality, ward No. 5, Budhi

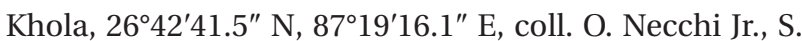
K. Rai, J. A. West and E. K. Ganesan, Feb 21, 2018 (SJRP 32580).

Etymology. The species epithet indicates the known geographic distribution of the species in India and Nepal.

DNA sequences. MN487449, MN487060.

Remarks. The population from Nepal had more robust plants (larger whorls and higher fascicle cells), longer carpogonial branches and larger spermatangia and carpospophytes than all other populations of Sheathia examined in this study (Table 2). Despite these morphological differences, the sequence divergence of the population from India (1\%) is within the currently accepted ranges to be interpreted as a single species (up to $2.5 \%$ ) in members of the Batrachospermales (Necchi et al. 2019b and references therein).

\section{Sheathia dispersa Necchi, J. A. West, E. K. Ganesan et S.}

K. Rai sp. nov. (Fig. 5A-E)

Description. Plants dioecious, irregularly branched. Male and female plants with confluent or separated, barrel-shaped or spherical whorls, 483-1,316 $\mu$ m wide. Primary fascicles straight, with curved distal ends, with 11-18 cell layers; proximal cells cylindrical or ellipsoid, distal cells ellipsoid or obovoid; secondary fascicles lacking. Internode 332-754 $\mu \mathrm{m}$ long. Cortication of the main axis with two or three layers of filaments, composed only of cylindrical cells, 5.3-8.3 $\mu \mathrm{m}$ wide. Spermatangia spherical or obovoid, terminal on primary fascicles, 5.8$8.1 \mu \mathrm{m}$ wide. Carpogonial branches composed of 3-8 cylindrical or ellipsoid cells, developing from the periaxial cells or proximal cells of primary fascicles 35.0-94.8 $\mu \mathrm{m}$ long; involucral filaments composed of 1-5 ellipsoidal or fusiform cells; carpogonia 20.6-29.6 $\mu \mathrm{m}$ long, with sessile, club-shaped trichogynes. Carposporophytes pedunculate, spherical or subspherical, contained within the whorls or exerted, 1-5 per whorl, small, 97.0-235.0 $\mu \mathrm{m}$ in diameter; gonimoblast filaments densely arranged, composed of two to four cylindrical or barrel-shaped cells; carposporangia obovoid, pear-shaped or sub-spherical,
13.0-20.0 $\mu \mathrm{m}$ long, 7.8-12.2 $\mu \mathrm{m}$ wide.

Holotype. Nepal, Province No. 1, Koshi Zone, Morang District, Sundarharaicha Municipality, ward No. 5, Khay-

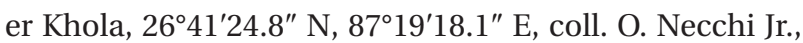
S. K. Rai, J. A. West and E. K. Ganesan, Feb 21, 2018 (SJRP 32578).

Paratype. Nepal, Province No. 1, Koshi Zone, Morang District, Sundarharaicha Municipality, ward No. 5, Lati Khola, $26^{\circ} 42^{\prime} 10.9^{\prime \prime}$ N, $87^{\circ} 19^{\prime} 15.8^{\prime \prime}$ E, coll. O. Necchi Jr., S. K. Rai, J. A. West and E. K. Ganesan, Feb 21, 2018 (SJRP 32579).

Etymology. The species epithet refers to the known geographic distribution of the species that is broadly disperse across regions of Asia (Indonesia, Nepal and Taiwan) and in the Hawaian Archipelago.

DNA sequences. MN487058, MN487059.

Remarks. Most previous records of this species were from DNA sequences from the 'Chantransia' stage and the only report of gametophytes were from specimens from Taiwan (as S. arcuata) by Vis et al. (2010). Since the specimens from Taiwan are not available, we had to rely only on our material from Nepal to designate the types.

\section{DISCUSSION}

With these three new proposed species, the number of species in the S. arcuata complex is now raised to seven. Based on the current available information they are all cryptic species that can be distinguished only on the basis of DNA sequence data ( $r b c \mathrm{~L}$ and COI-5P). A full account on the species delimitation within $S$. arcuata species complex is being carried out by Vis et al. (personal communication) including previously published and newly generated sequences and is outside the scope of this study.

All species within the complex are homocorticated (with only cylindrical cells in the cortical filaments), which represents an exception in the genus Sheathia. Salomaki et al. (2014) found that the $r b c \mathrm{~L}$ phylogenetic tree highly supported the clade including S. exigua, a species with heterocortication, as basal to S. arcuata. From this result, they inferred that heterocortication was shared by a common ancestor of taxa in Sheathia, which has been lost by S. arcuata. Our tree also showed S. exigua as a basal clade in the $S$. arcuata species complex, although not well supported, and we found this hypothesis of loss of heterocortication as plausible.

A comparison of the present data with the single report of Sheathia from India (Balakrishnan and Chaugule 
1980) is not conclusive, mostly due to the imprecise descriptions provided. Several species of Sheathia could be fitted within the description by those authors.

The finding of two new species occurring only in the region surveryed suggests high species endemism. Genetic diversity was high, as well as the fact that in the phylogenetic analysis sequences of one species (S. assamica sp. nov.) revealed a distant relationship from the other two species here described but close to samples from New Zealand and United States. In addition, we found species with restricted distribution (S. assamica), as well as species with a broad range of distribution $(S$. dispersa). This set of information indicates a high diversity of the genus Sheathia in northeast India and east Nepal. Such high diversity is somewhat expected since the regions sampled are part of a biodiversity hotspot called the Eastern Himalaya Biodiversity Hotspot (Allen et al. 2010). Land plant endemism (more than 1,500 endemic species) and very speciose groups of organisms, (more than $25 \%$ of known species of aquatic plants) have been documented in the region (WWF-US, Asia Program 2005, Allen et al. 2010) The high diversity found in the genus Sheathia corroborates the Eastern Himalaya as a hotspot of biodiversity.

\section{ACKNOWLEDGEMENTS}

Necchi and Rossignolo are grateful to Brazilian agencies CNPq (Proc. 302415/2017-3) and FAPESP (2016/07808-1, 2016/16320-2) for financial support by grant and scholarship; to Beatriz G. Ricardo for help in laboratory work. Kanchi Gandhi for the advice on the specific epithets for the new species. Dilli Rai for his unstinted help during our field work in Nepal. Yasmin thankfully acknowledge the financial support of Department of Biotechnology, Government of India through Institutional Biotech Hub (No. BT/04/NE/2009).

\section{REFERENCES}

Allen, D. J., Molur, S. \& Daniel, B. A. 2010. The status and distribution of freshwater biodiversity in the Eastern $\mathrm{Hi}$ malaya. International Union for Conservation of Nature (IUCN), Cambridge, 88 pp.

Balakrishnan, M. S. \& Chaugule, B. B. 1980. Indian Batrachospermaceae. In Desikachary, T. V. \& Raja Rao, V. N. (Eds.) Taxonomy of Algae. University of Madras, Chennai, pp. 223-248.
Darriba, D., Taboada, G. L., Doallo, R. \& Posada, D. 2012. jModelTest 2: more models, new heuristics and parallel computing. Nat. Methods 9:772.

Entwisle, T. J., Vis, M. L., Chiasson, W. B., Necchi, O. Jr. \& Sherwood, A. R. 2009. Systematics of the Batrachospermales (Rhodophyta): a synthesis. J. Phycol. 45:704-715.

Everitt, B. S. \& Dunn, G. 2001. Applied multivariate data analysis. 2nd ed. Wiley, Chichester, $373 \mathrm{pp}$.

Ganesan, E. K., West, J. A. \& Necchi, O. Jr. 2018. A catalogue and bibliography of non-marine (freshwater and estuarine) Rhodophyta (red algae) of India. Phytotaxa 364:148.

Garbary, D. J. \& Gabrielson, P. W. 1990. Taxonomy and evolution. In Cole, K. M. \& Sheath, R. G. (Eds.) Biology of the Red Algae. Cambridge University Press, Cambridge, pp. 477-498.

Guiry, M. D. \& Guiry, G. M. 2019. AlgaeBase. World-wide electronic publication, National University of Ireland, Galway. Available from: http://www.algaebase.org. Accessed Aug 15, 2019.

Kumano, S. 2002. Freshwater red algae of the world. Biopress, Bristol, 375 pp.

Müller, K. M., Sherwood, A. R., Pueschel, C. M., Gutell, R. R. \& Sheath, R. G. 2002. A proposal of a new red algal order, the Thoreales. J. Phycol. 38:807-820.

Necchi, O. Jr., Garcia Filho, A. \& Paiano, M. O. 2019a. Revision of Batrachospermum sections Acarposporophytum and Aristata (Batrachospermales, Rhodohyta) with the establishment of the new genera Acarposporophycos and Visia. Phytotaxa 395:51-65.

Necchi, O. Jr., Garcia Fo, A. S., Paiano, M. O. \&Vis, M. L. $2019 b$. Revision of Batrachospermum section Macrospora (Batrachospermales, Rhodophyta) with the establishment of the new genus Montagnia. Phycologia Advanced online publication. https://doi.org/10.1080/00318884.201 9.1624143.

Necchi, O. Jr. \& Zucchi, M. R. 1997. Taxonomy and distribution of Thorea (Thoreaceae, Rhodophyta) in Brazil. Algol. Stud. 84:83-90.

Pueschel, C. M. \& Cole, K. M. 1982. Rhodophycean pit plugs: an ultrastructural survey with taxonomic implications. Am. J. Bot. 69:703-720.

Ronquist, F. \& Huelsenbeck, J. P. 2003. MrBayes 3: Bayesian phylogenetic inference under mixed models. Bioinformatics 19:1572-1574.

Rossignolo, N. L. \& Necchi, O. Jr. 2016. Revision of section Setacea of the genus Batrachospermum (Batrachospermales, Rhodophyta) with emphasis on specimens from Brazil. Phycologia 55:337-346.

Salomaki, E. D., Kwandrans, J., Eloranta, P. \& Vis, M. L. 2014. 
Molecular and morphological evidence for Sheathia gen. nov. (Batrachospermales, Rhodophyta) and three new species. J. Phycol. 50:526-542.

Shrestha, B. \& Manandhar, J. D. 1983. Contribution to the algal flora of Kathmandu valley. J. Inst. Sci. Technol. 6:1-6.

Silvestro, D. \& Michalak, I. 2012. raxmlGUI: a graphical frontend for RAxML. Org. Divers. Evol. 12:335-337.

Thiers, B. 2019. Index Herbariorum: a global directory of public herbaria and associated staff. New York Botanical Garden's Virtual Herbarium. Available from: http:// sciweb.nybg.org/science2/IndexHerbariorum.asp. Accessed Aug 15, 2019.
Vis, M. L., Feng, J., Chiasson, W. B., Xie, S. L., Stancheva, R., Entwisle, T. J., Chou, J. -Y. \& Wang, W. 2010. Investigation of the molecular and morphological variability in Batrachospermum arcuatum (Batrachospermales, Rhodophyta) from geographically distant locations. Phycologia 49:545-553.

WWF-US, Asia Program. 2005. Critical Ecosystem Partnership Fund (CEPF). Ecosystem profile: Eastern Himalayas region. Available from:https://www.cepf.net/sites/ default/files/final.ehimalayas.ep_.pdf. Accessed Aug 15, 2019. 